\title{
9. Innovation and future challenges
}

\subsection{INTRODUCTION}

This chapter draws upon the earlier chapters of this book to comment on innovation measurement and how it might be of use in monitoring or evaluating policies. What is different is that the innovation discussed here may be happening in any or all of the economic sectors, not just the business sector, and the activities in the sectors may be linked. This emphasizes the systems dimension as part of understanding the role of innovation and the monitoring and evaluation of innovation policy.

The world is changing rapidly, and, for some time, there has been policy interest in sustainable development and climate change, topics which overlap. While the environment is changing in response to human activity, the economy is changing as it becomes progressively more digital. The challenge is understanding these changes, through statistical measurement, leading to indicators that inform policy development, and not just measurement of activities in economic sectors, in isolation.

In 2015 the 17 Sustainable Development Goals (SDGs) (Box 9.1) were introduced with the expectation that the targets would be met by 2030 (United Nations 2015). The task in this chapter, indeed in this book, is to examine how understanding innovation, in any or all economic sectors, can help. This is not as simple as it might seem.

Turning to climate change, there is a Framework for the Development of Environmental Statistics (FDES) but there is no reference to 'innovation' in the indicators present in the framework. As with the SDGs, the absence of 'innovation' is an issue considered here.

'Green growth' and the expectation that green activities and innovation protect the environment while generating economic growth are considered, as are innovation policies for inclusive growth. In both cases, the importance of the innovation systems approach and analysis of innovation is emphasized. 
International health issues are considered and the capacity for innovation in a number of economic sectors to deal with the threats to health. This includes threats to cyber security in the health care system.

The chapter concludes with future directions for innovation measurement, policy monitoring and evaluation leading to policy learning.

\subsection{SUSTAINABLE DEVELOPMENT GOALS AND MEASUREMENT}

The definition of 'sustainable development' used in the SDGs is the following:[]

Sustainable development is development that meets the needs of the present without compromising the ability of future generations to meet their own needs.

\section{BOX 9.1 SUSTAINABLE DEVELOPMENT GOALS}

A. People

Goal 1. End poverty in all its forms everywhere

Goal 2. End hunger, achieve food security and improved nutrition and promote sustainable agriculture

Goal 3. Ensure healthy lives and promote well-being for all at all ages

Goal 4. Ensure inclusive and equitable quality education and promote lifelong learning opportunities for all

Goal 5. Achieve gender equality and empower all women and girls

B.

Planet

Goal 6. Ensure availability and sustainable management of water and sanitation for all

Goal 12. Ensure sustainable consumption and production patterns 
Goal 13. Take urgent action to combat climate change and its impacts*

Goal 14. Conserve and sustainably use the oceans, seas and marine resources for sustainable development

Goal 15. Protect, restore and promote sustainable use of terrestrial ecosystems, sustainably manage forests, combat desertification, and halt and reverse land degradation and halt biodiversity loss

\section{Prosperity}

Goal 7. Ensure access to affordable, reliable, sustainable and modern energy for all

Goal 8. Promote sustained, inclusive and sustainable economic growth, full and productive employment and decent work for all

Goal 9. Build resilient infrastructure, promote inclusive and sustainable industrialization and foster innovation

Goal 10. Reduce inequality within and among countries

Goal 11. Make cities and human settlements inclusive, safe, resilient and sustainable

D.

Peace

Goal 16. Promote peaceful and inclusive societies for sustainable development, provide access to justice for all and build effective, accountable and inclusive institutions at all levels

E.

Partnership

Goal 17. Strengthen the means of implementation and revitalize the Global Partnership for Sustainable Development

Note: $\quad$ * United Nations (2015) acknowledges that the United Nations Framework Convention on Climate Change is the primary international, intergovernmental forum for negotiating the global response to climate change.

Source: United Nations (2015:14). 
Looking at the SDGs in Box 9.1, it is clear that there is no substantive use of the word 'innovation'. It appears once, in the title of SDG 9; innovation is to be 'fostered'. Each SDG has a number of sub-goals, for a total of 169 (United Nations 2015), and for each sub-goal there are indicators, of which 232 are unique. There are six occurrences of 'innovation' in the 169 sub-goals and none in the 232 indicators (United Nations 2019a). What is the role of innovation in the SDGs?

The SDGs (Box 9.1) provide (non-obligatory) targets for the year 2030 for participating countries (United Nations 2015). There are 17 goals with the 17th being the implementation of the other 16. In Box 9.1 the SDGs are divided into five categories: People (1-5); Planet $(6,12-15)$; Prosperity (7-11); Peace (16); and implementation of the 17 goals (17).

The SDGs are seen by some as targets for developing countries, as were the Millennium Development Goals (MDGs), however, in the UK, 30 per cent of children were in poverty in 2017/18 after housing costs were taken into account (Francis-Divine et al. 2019: 12), and in the EU, 'Almost every fourth person in the EU is still at risk of poverty or social exclusion ...' (Eurostat 2018). Poverty, SDG 1, is a global issue as are the other SDGs.

As the focus of this book is on the measurement of innovation and the use of the resulting indicators to support government policy, business strategy or household planning, the five categories of the SDGs are examined from an innovation measurement perspective. This is not a comprehensive analysis, but an indicative one suggesting, based on the sub-goals that mention innovation, areas in which statistical measures of innovation could contribute to the monitoring of selected SDGs as new indicators are developed in later stages of the SDG process.

\subsubsection{People}

There is no reference to innovation in goals $1-5$, but there is scope for innovation indicators that show new or improved products or processes that are made available to potential users or brought into use in the institutional unit and have outcomes that change the state of poverty, ideally reducing it. The institutional units could be in any economic sector, including government departments, education institutions, hospitals, health care services, businesses, households and non-profit organisations serving households. 


\subsubsection{Planet}

Goals $6,12-16$ address issues affecting the planet. There is no reference to innovation in the goals, the sub-goals or the indicators.

\subsubsection{Prosperity}

Goals 7-11 deal with the economy. In sub-goals 8.2 and 8.3 there is reference to innovation. Sub-goal 8.2 is to: 'Achieve higher levels of economic productivity through diversification, technological upgrading and innovation, including through a focus on high-value added and labour-intensive sector'. The indicator is 8.2.1, 'The annual growth rate of real GDP per employed person'.

Sub-goal 8.3 is to: 'Promote development-oriented policies that support productive activities, decent job creation, entrepreneurship, creativity and innovation, and encourage the formalisation and growth of micro-, small- and medium-sized enterprises, including through access to financial services'. The indicator is 8.3.1, 'Proportion of informal employment in non-agriculture employment, by sex'.

In both sub-goals 8.2 and 8.3 , innovation is promoted but there is no guidance on measuring innovation and its impact on the institutional units that are involved in achieving the sub-goals as part of achieving SDG 8 .

In SDG 9, an objective is to 'foster innovation'. This arises in two sub-goals, 9.5 and 9.b.

Sub-goal 9.5 is to: 'Enhance scientific research, upgrade the technological capabilities of industry sectors in all countries, in particular developing countries, including, by 2030, encouraging innovation and substantially increasing the number of research and development workers per 1 million people and public and private research and development spending'. There are two indicators, 9.5.1, 'Research and development expenditure as a proportion of GDP'; and 9.5.2, 'Researchers (full-time equivalents) per million inhabitants'. The indicators deal with the allocation of resources, financial and human, to the performance of R\&D. However, R\&D is not innovation.

Sub-goal 9.b is to 'Support domestic technology development, research and innovation in developing countries, including by ensuring a conducive policy environment for, inter alia, industrial diversification and value addition to commodities'. The indicator is 9.b.1, 'Proportion 
of medium and high-tech industry value added in total value added'. As with Goal 8, 'innovation' is not present in the indicator.

\subsubsection{Peace}

There is no reference to innovation in Goal 16, but there are opportunities to develop policies on public sector innovation and indicators that could be used once the policies had been implemented.

\subsubsection{Partnership}

Goal 17 deals with implementation of the other 16 goals. Innovation appears in two sub-goals, 17.6 and 17.8, under the heading of technology.

Sub-goal 17.6 is to 'Enhance North-South, South-South and triangular regional and international cooperation on and access to science, technology and innovation and enhance knowledge-sharing on mutually agreed terms, including through improved coordination among existing mechanisms, in particular at the United Nations level, and through a global technology facilitation mechanism'. There are two indicators, 17.6.1 and 17.6.2, but neither deals with innovation.

Sub-goal 17.8 is to 'Fully operationalize the technology bank and science, technology and innovation capacity-building mechanism for least developed countries by 2017 and enhance the use of enabling technology, in particular information and communications technology'. There is one indicator, 17.8.1, 'Proportion of individuals using the Internet'.

The 18 sub-goals of Goal 17 deal with finance, technology, capacity building, trade and systemic issues. Each of these topics is an area for public sector innovation, links to international organisations, and business sector innovation, linked to trade rules, and policy coherence.

In summary, 'innovation' appears in the text of six sub-goals: 8.2, 8.3, 9.5, 9.b, 17.6 and 17.8. It does not appear in any of the indicators. The observation is made in OECD (2019c: 19) that the 2030 Agenda was 'politically driven rather than based on a conceptual framework' and the 169 targets are heterogeneous. The issue here is not the heterogeneity but the understanding that could result from adding indicators, based on the direct measurement of innovation, related to sustainable development. That is an opportunity for future work on sustainable development and the role of innovation and the development of policy in any economic 
sector that supports the SDGs. This also fits with the work of the Global Partnership for Sustainable Development.

\subsection{CLIMATE CHANGE}

\subsubsection{The UN Framework Convention on Climate Change}

Climate change has been an issue for decades and more formally after the Rio Earth Summit in 1992. The UN Framework Convention for Climate Change (UNFCCC) started there and was released on 21 March 1994. The Kyoto Protocol, linked to the UNFCCC, came into being on 16 February 2005, ending in 2012. The Paris Agreement builds on the UNFCCC and became effective on 4 November 2016.

Measurement activities related to climate change have focused on the temperature of the planet, greenhouse gas emissions and gases damaging the ozone layer. The Paris Agreement includes proposals for mitigation of climate changef which could be part of an innovation policy in a participating country, but the term 'innovation' is not prominent.

There is work by the UN Statistics Division fon 'climate change statistics and indicators and adaptation-related SDG indicators' where 'adaptation' describes, with 'mitigation', the human response to climate change. The following SDG indicators in Table 9.1 are identified and related to the corresponding statistics from the FDES. The point has already been made that innovation is not prominent in indicators used to describe the SDGs. In the FDES (United Nations 2017), 'innovation' appears once, in a quotation of OECD work on green growth (para. B. 23).

As with the SDGs, there is knowledge to be gained from the direct measurement of innovation related to climate change, in any economic sector.

\subsection{GREEN GROWTH AND ECO-INNOVATION}

In 2009, 34 Member Countries of the OECD provided a mandate to the OECD to develop a Green Growth Strategy which was delivered in 2011. A definition was provided: 'Green growth means fostering economic growth and development, while ensuring that natural assets continue to provide the resources and environmental services on which our well-being relies. To do this, it must catalyse investment and innovation which will underpin sustained growth and give rise to new economic opportunities' (OECD 2011: 4). 
Table 9.1 SDG sub-goals related to the corresponding FDES statistics

\begin{tabular}{ll}
\hline SDG sub-goal & Content \\
\hline 1.5.3/11.b.2/13.1.2 & $\begin{array}{l}\text { Number of countries that adopt and implement disaster risk reduction } \\
\text { strategies }\end{array}$ \\
4.7.1(ii) & $\begin{array}{l}\text { Extent to which education for sustainable development is mainstreamed } \\
\text { at all levels }\end{array}$ \\
Change in water use efficiency over time \\
7.4.1 & Renewable share in the total final energy consumption \\
11.4.1 & $\begin{array}{l}\text { Total expenditure per capita on preservation, protection and } \\
\text { conservation of all cultural and natural heritage }\end{array}$ \\
11.c.1 & $\begin{array}{l}\text { Proportion of financial support to the least developed countries that is } \\
\text { allocated to the construction and retrofitting of sustainable, resilient, and } \\
\text { resource-efficient buildings using local materials }\end{array}$ \\
12.5.1 & National recycling rate, tons of material recycled \\
12.a.1 & $\begin{array}{l}\text { Amount of support to developing countries on research and } \\
\text { development for sustainable consumption and production and } \\
\text { environmentally sound technologies }\end{array}$ \\
& $\begin{array}{l}\text { Amount of fossil-fuel subsidies per unit GDP and as a proportion of } \\
\text { total national expenditure on fossil fuels } \\
\text { 12.c.1 }\end{array}$ \\
Number of countries that have integrated mitigation, adaptation, impact \\
reduction and early warning into primary, secondary and tertiary \\
curricula \\
Coverage of protected areas in relation to marine areas \\
Proportion of land that is degraded over total land area
\end{tabular}

Source: UN Statistics Division (2018, 2019a, 2019b).

The European Commission promotes green growth and the circular economy, and, in a separate project, a team has developed the Maastricht Manual on Measuring Eco-Innovation, Green Growth and the Green Economy (Kemp et al. 2019).

Both the OECD and the EC activities provide a basis for innovation policy implementation and statistical measurement in all economic sectors. Governments can take direct initiatives or provide framework conditions that influence green growth or innovation. Firms can engage in product or process innovation that takes account of green growth or eco-innovation. Indeed, they may take advantage of regulation to innovate and capture more of the market or avoid taxes on activities that are not green or ecologically sound. 
With innovation happening and being measured in all economic sectors, there is an opportunity to identify and measure linkages between the actors in the different sectors.

The Maastricht Manual provides guidance on measuring eco-innovation and it will be a basis for an ongoing discourse on eco-innovation and how to measure it. The experience from the OECD is that, once there is a manual, Member Countries will learn from their measurement experience and seek to revise the manual, a matter that requires a consensus of OECD Member Countries. The team responsible for the Maastricht Manual may wish to seek an institutional home for the project so that there is a centre for discourse among experts, collective learning and revision of the manual.

\subsection{INNOVATION AND INCLUSIVE GROWTH}

While innovation is being promoted to address the issues just discussed, inequality has been growing in developed (OECD 2008, 2015b) and developing (Cozzens and Thakur 2014; Dutrénit and Sutz 2014) countries.

'Green growth' and 'innovation and inclusive growth' are expected to provide economic growth and additional outcomes; green activities and inclusion. These additional outcomes fit into the category of 'restricted' innovation (Chapters 5 and 6). However, the point is made by the OECD (2015b: 61) that inclusive innovation policies and their evaluation mechanisms are still experimental and can benefit from 'trial and error'. This echoes the history of the measurement of innovation in the business sector where over a decade was spent engaging in 'trial and error' before a consensus was reached on the definition of innovation and the first edition of the Oslo Manual (OECD 1992) was published.

Throughout this book, the point has been made that the statistical measurement of innovation produces indicators that can be used for monitoring and evaluation leading to policy learning. In the case of innovation for inclusive growth, this is a work in progress but there is a need for policy research, experimentation and monitoring, resulting in improved policy. There is also a need for international openness (OECD 2015d:61). This has been the role of NESTI for the development of the definition of innovation for use in the business sector and, in the fourth edition of the Oslo Manual (OECD/Eurostat 2018), for all economic sectors.

From a measurement perspective, so long as there is an agreed definition of 'inclusive innovation', data can be gathered from the economic 
sectors which contribute to inclusive innovation and used to produce indicators that support monitoring and evaluation of inclusive innovation policies.

Planes-Satorra and Paunov (2017) review the subject and provide examples of inclusive innovation. They start with a review of innovation policy and then go on to inclusive innovation policy, dividing it into three categories, social inclusiveness, industrial inclusiveness and territorial inclusiveness. These categories can be elaborated to provide a definition for statistical measurement of restricted innovation.

For inclusive innovation the authors identify ten activities:

- building capacities

- addressing discrimination and stereotypes

- providing incentive to invest in inclusive innovation

- facilitating access to finance

- providing business development support

- promoting networks

- improving access to talent by small businesses

- accessing global knowledge and technology

- maximising the potential of existing assets

- attracting innovative firms to peripheral regions.

Innovation policies are then discussed and examples in various countries provided. Inclusive innovation policy can involve government policy, business strategy and household practices, suggesting that the introduction of policy, strategy or practices could benefit from better information on links to all sectors and using the general definition of innovation.

\subsection{HEALTH ISSUES}

Innovation in all economic sectors can address health problems arising from diseases, lifestyle or cyber security failures.

Smallpox virus has been eradicated but the virus is still held in two laboratories, one in the US, one in Russia. In September 2019 there was an explosion in the Russian laboratory but there was no release of the virus. The debate on whether to destroy the viruses held continues. As people refuse to have their children vaccinated, measles, which had almost been eliminated in developed countries, is returning. Ebola virus is active in Africa and could move to other continents. Malaria treatment 
is becoming difficult as strains of the parasite are becoming more drug resistant. There are other examples.

While viruses and parasites evolve, so does the use of cyber tools in health care, raising cyber security] issues (Ghafur et al. 2019).

Addressing these issues is a challenge for innovation in all economic sectors. There may be a case for coordination of innovation through linkages of the actors in different sectors to collaborate to arrive at the desired outcome.

\subsection{CONCLUSION}

In this chapter a selection of global challenges was reviewed to explore the use of innovation policy in participating countries to address the challenges.

In the Sustainable Development and the Climate Change goals, the use of innovation policy is very limited, leading to a suggestion that innovation policy be developed to address these global challenges and that the general definition of innovation (Chapter 6) and the systems approach (Chapter 2) be used to monitor and evaluate implemented innovation policy dealing with these global challenges. Going back a decade, there was an ongoing discussion of the need to initiate innovation policy to deal with the financial crisis of 2008 and to monitor and evaluate policies, once they were implemented, in order to benefit from policy learning which would improve the policy intervention and result in better outcomes (Gault 2010). The same needs are present when dealing with sustainable development and trying to mitigate climate change. The difference since 2008 is the presence of a general definition of innovation that can be used to measure activities related to the SDGs and to climate change, including the linkages between the actors and their impacts on the outcomes of policies. Promoting innovation policy and the measurement of innovation, once the policy was implemented, would increase knowledge of sustainable development and of climate change.

Work on green growth and eco-innovation makes use of innovation, as demonstrated by the OECD Green Growth Strategy (OECD 2011) and the Maastricht Manual on Measuring Eco-innovation, Green Growth and the Green Economy (Kemp et al. 2019). Green growth and eco-innovation can happen in any economic sector and links between actors within sectors and across sector boundaries provide information on how policy is functioning. As noted in the text, as part of advancing the understanding of green growth and eco-innovation, the Maastricht 
Manual needs to find an institutional home where participating countries can use it to guide data gathering and analysis and then to support future developments of the manual.

Innovation and inclusive growth have been part of the innovation measurement discourse for at least a decade and it is covered in this book by 'restricted' innovation introduced in Chapters 5 and 6. While the measure tools are present, work at the OECD (2015d) shows that measurement and evaluation are still developing in the same way as the measurement of innovation in the business sector in the years leading up to the first Oslo Manual in 1992. The suggestion is, as with the Maastricht Manual, that an institutional home be found to maintain the discourse on inclusive innovation and growth and to support possible manuals in the future

Health issues, including those related to social care, invite innovation policy in health in all sectors and statistical measurement of the results of implemented innovation policy.

There is much to do, but the knowledge and capacity are present in statistical offices and research institutes to do it.

\section{NOTES}

1. See 'What is SD' in https://www.un.org/sustainabledevelopment/ development-agenda/ (accessed 17 March 2020) or World Commission on Environment and Development (1987).

2. These categories are taken from OECD (2019c). They are not unique and are used to develop the measurement requirements. Other categories could be used (Gault 2018b).

3. See http://www.data4sdgs.org/index.php/about-gpsdd (accessed 17 March 2020).

7. See https://unfccc.int/resource/bigpicture/\#content-the-paris-agreemen (accessed 17 March 2020).

5. See https://www.unece.org/fileadmin/DAM/stats/documents/ece/ces/ge.33/ 2018/mtg4/S2_3_UNSD_CC_rev.pdf (accessed 17 March 2020).

6. See https://ec.europa.eu/environment/green-growth/index_en.htm (accessed 17 March 2020).

7. As an example, see the call for a green growth project in Denmark, https:// innovationsfonden.dk/en/programmes/grand-solutions/green-growth.

8. See http://www.centerforhealthsecurity.org/our-work/events/2001_dark -winter/about.html (accessed 17 March 2020) for an experiment which examined the response to the release of a smallpox or similar virus.

9. The digital economy and cybercrime are considered in Chapter 10. 